\title{
Analisis Faktor-faktor yang Mempengaruhi Impor Daging Sapi di Indonesia Periode 1988-2017: Menggunakan Metode VECM (Vector Error Correction Model)
}

\author{
Farida Dwi Prasetyawati ${ }^{1}$, dan Agus Tri Basuki ${ }^{1}$
}

\section{רoper}

\section{AFILIASI:}

${ }^{1}$ Department of Economics, Faculty of Economics and Business, Universitas Muhammadiyah Yogyakarta, Yogyakarta, Indonesia.

*KORESPONDENSI:

farida.dwi.2015@fe.umy.ac.id

ARTIKEL INI TERSEDIA DI:

http://journal.umy.ac.id/index.php/jerss

DOI: 10.18196/jerss.030213

SITASI:

Prasetyawati, F. D., \& Basuki, A. T. (2020). Analisis Faktor-faktor yang Mempengaruhi Impor Daging Sapi di Indonesia Periode 1988-2017: Menggunakan Metode VECM (Vector Error Correction Model). Journal of Economics Research and Social Sciences, 4(1), 118-133.

\begin{abstract}
Abstrak: Data menunjukkan bahwa dari 5 tahun terakhir dimana jumlah penduduk semakin meningkat dari tahun 2013 hingga 2017, begitupula dengan impor barang konsumsi semakin tahun semakin meningkat walaupun terdapat penurunan pada tahun 2015. Produksi daging sapi di Indonesia sebenarnya pada tahun 2013 dan 2014 melebihi data konsumsi permintaan masyarakat Indonesia. Tentu ini menjadi hal yang menarik di mana seharusnya produksi daging sapi yang ada pada tahun 2013 dan 2014 mampu mencukupi kebutuhan pada tahun tersebut. Akan tetapi justru pada tahun tersebut Pemerintah Indonesia memberikan kebijakan impor.Penelitian ini menggunakan jenis kuanitatif. Metode kuantitatif ini menggunakan metode VECM (Vector Error Correction Model). Hasil penelitian ini menunjukkan dalam jangka pendek, PDB pada lag 1 (+) berpengaruh signifikan dan inflasi pada lag $1(-)$ serta berpengaruh signifikan terhadap impor daging sapi di Indonesia. Sedangkan, produksi daging sapi, jumlah penduduk dalam jangka pendek tidak menunjukkan pengaruh yang signifikan terhadap impor daging sapi dilndonesia. Dalam jangka panjang, produksi daging sapi pada lag $1(+)$ berpengaruh signifikan, PDB pada lag $1(-)$ berpengaruh signifikan dan inflasi pada lag 1 (-) berpengaruh signifikan terhadap impor daging sapi di Indonesia. Sedangkan, jumlah penduduk dalam jangka panjang tidak menunjukkan pengaruh yang signifikan terhadap impor daging sapi. Dalam jangka panjang, produksi daging sapi pada lag $1(+)$ berpengaruh signifikan, PDB pada lag 1 (-) berpengaruh signifikan dan inflasi pada lag $1(-)$ berpengaruh signifikan terhadap impor daging sapi di Indonesia. Sedangkan, jumlah penduduk dalam jangka panjang tidak menunjukkan pengaruh yang signifikan terhadap impor dagings api.
\end{abstract}

Kata Kunci: Impor; Produksi Daging Sapi; PDB; Jumlah Penduduk; Inflasi.

\section{Pendahuluan}

Indonesia adalah negara sedang berkembang dimana memiliki jumlah penduduk sebanyak 261.890 juta jiwa pada tahun 2017. Mencakup di daerah perkotaan dan daerah perdesaan. Diketahui jumlah pertumbuhan penduduk begitu banyak memiliki tantangan yang cukup besar untuk menghasilkan barang dan jasa yang diperoleh setiap penduduk. Dimana tingkat konsumsi masyarakat yang semakin meningkat dipicu oleh pertumbuhan jumlah penduduk untuk dapat mendorong Indonesia melakukan perdagangan Internasional dengan mengimpor barang konsumsi untuk memenuhi kebutuhan masyarakat. Sumber mata 
pencaharian penduduk Indonesia sebagian besar dari sektor pertanian dan peternakan. Dimana bukan hanya karbohidrat seperti beras saja yang dibutuhkan oleh masyarakat tetapi juga kebutuhan akan protein sepeti daging.

Menurut (Sudarmono, 2018) Ternak sapi khususnya sapi potong, merupakan salah satu sumber daya penghasil daging yang memiliki nilai ekonomi tinggi, dan penting artinya bagi kehidupan masyarakat. Seekor ternak mampu menghasilkan berbagai macam kebutuhan, terutama sebagai bahan makanan berupa daging, susu dan hasil ikutannya seperti pupuk kandang, kulit dan tulang. Sapi potong merupakan salah satu ternak yang dimanfaatkan sebagai penyedia kebutuhan daging dan memiliki potensi untuk dikembangkan.

Seiring dengan peningkatan kesadaran masyarakat Indonesia akan pentingnya protein hewani untuk kesehatan dan kecerdasan maka kebutuhan permintaan daging khususnya daging sapi menjadi semakin meningkat. Sementara itu populasi ternak sapi di dalam negeri tidak dapat mencukupi kebutuhan jumlah penduduk Indonesia, maka dibutuhkan adanya suatu impor barang konsumsi (daging sapi) untuk mencapai kebutuhan akan protein hewani tersebut. Dengan demikian dapat dilihat dari data impor barang konsumsi di Indonesia.

Tabel 1 Jumlah Penduduk, Impor Barang Konsumsi, 2013-2017

\begin{tabular}{|ccc|}
\hline Tahun & $\begin{array}{c}\text { Jumlah Penduduk } \\
\text { (Jiwa) }\end{array}$ & $\begin{array}{c}\text { Impor Barang Konsumsi } \\
\text { (Ton) }\end{array}$ \\
\hline $\mathbf{2 0 1 3}$ & 249.853 .800 & 5.285 .7 \\
$\mathbf{2 0 1 4}$ & 253.308 .000 & 5.599 .1 \\
$\mathbf{2 0 1 5}$ & 255.461 .700 & 4.929 .2 \\
$\mathbf{2 0 1 6}$ & 258.705 .000 & 5.899 .5 \\
$\mathbf{2 0 1 7}$ & 261.890 .900 & 5.315 .0 \\
\hline
\end{tabular}

Sumber : Badan Pusat Statistik 2017

Dari data di atas menunjukkan bahwa dari 5 tahun terakhir dimana jumlah penduduk semakin meningkat dari tahun 2013 hingga 2017, begitupula dengan impor barang konsumsi semakin tahun semakin meningkat walaupun terdapat penurunan pada tahun 2015, tetapi penurunan tersebut tidak berlangsung lama karena tingkat kebutuhan akan barang konsumsi semakin meningkat setiap tahunnya. Tidak bisa dipungkiri bahwa barang konsumsi adalah mutlak bagi manusia dalam keberlangsungan hidupnya dan barang konsumsi yang ada di Indonesia juga terbatas. Karena banyaknya jumlah penduduk dan tingginya permintaan akan konsumsi dalam negeri, sehingga dilakukannya impor untuk memenuhi kebutuhan dalam negeri. 
Tabel 2 Data Produksi Daging Sapi, Konsumsi Daging Sapi, Impor Daging Sapi, Presentase\%.

\begin{tabular}{cccc}
\hline & $\begin{array}{c}\text { Tahun } \\
\text { (Ton) }\end{array}$ & & Impor Daging Sapi (ton) \\
\hline $\mathbf{2 0 1 3}$ & 504,82 & 2,305 & 130.021 \\
2014 & 497,67 & 2,364 & 246.609 \\
2015 & 506,66 & 2,249 & 197.604 \\
$\mathbf{2 0 1 6}$ & 524,11 & 2,310 & 145.536 \\
$\mathbf{2 0 1 7}$ & 531,76 & 2,399 & 87,196 \\
\hline
\end{tabular}

Sumber : Dinas Pertanian \& Badan Pusat Statistik (2017)

Dari tabel 2 dapat kita lihat bersama bahwa sebenarnya produksi daging sapi di Indonesia pada tahun 2013 dan 2014 melebihi data konsumsi permintaan masyarakat Indonesia. Tentu ini menjadi hal yang menarik di mana seharusnya produksi daging sapi yang ada pada tahun 2013 dan 2014 mampu mencukupi kebutuhan pada tahun tersebut. Akan tetapi justru pada tahun tersebut Pemerintah Indonesia memberikan kebijakan impor. Meskipun tidak bisa dipungkiri bahwa impor sendiri tidak hanya dipengaruhi oleh faktor internal saja. Hal-hal seperti intervensi politik, mafia daging, dan lain-lain tidak bisa dilepaskan begitu saja.

\section{Tinjauan Pustaka}

Syamsuddin, Hamzah, \& Nasir (2013), dalam penelitiannya menyimpulkan bahwa pengaruh antara harga beras (domestik), kurs dan PDB terhadap impor beras di Indonesia dimana apabila terjadi kenaikan harga beras sebesar 1 unit maka akan menyebabkan kenaikan impor pada impor beras di Indonesia. Menguatnya kurs sebesar 1 unit akan menyebabkan turunnya impor beras di Indonesia. Kenaikan PDB sebesar 1 unit akan menyebabkan penurunan impor beras di Indonesia.

Kurniyawan (2013), dalam penelitiannya menyimpulkan bahwa produksi beras dalam jangka pendek dan jangka panjang berpengaruh negatif dan signifikan terhadap perubahan impor beras di Indonesia. Jumlah penduduk dalam jangka panjang dan jangka pendek tidak berpengaruh secara signifikan terhadap impor beras di Indonesia. Produk domestik bruto(PDB) dalam jangka pendek tidak berpengaruh terhadap impor beras di Indonesia sedangkan dalam jangka panjang Produk domestik bruto berpengaruh positif dan signifikan terhadap impor beras di Indonesia.

Putra dan Rustariyuni (2015), dalam penelitiannya menyimpulkan bahwa Kurs dollar Amerika Serikat, harga domestik, jumlah produksi daging sapi berpengaruh secara simultan terhadap volume impor daging sapi di Indonesia. Kurs dollar Amerika Serikat, harga impor, harga domestik tidak berpengaruh secara parsial terhadap volume impor daging sapi di Indonesia. Sedangkan jumlah produksi berpengaruh negatif dan signifikan terhadap impor daging sapi di Indonesia.

Sari (2014), dalam penelitiannya menyimpulkan bahwa produksi beras dalam negeri berpengaruh negatif terhadap impor beras di Indonesia dalam jangka panjang maupun 
jangka pendek karena nilai probabilitasnya kurang dari $\alpha$ 5\%. Konsumsi beras dalam negeri berpengaruh positif terhadap impor beras di Indonesia dalam jangka panjang maupun pendek karena probabilitasya kurang dari $\alpha$ 5\%. Harga beras domestik berpengaruh positif terhadap impor beras di Indonesia dalam jangka panjang maupun pendek karena probabilitasnya kurang dari $\alpha 5 \%$. Nilai tukar rupiah terhadap dollar AS berpengaruh negatif terhadap impor beras di Indonesia dalam jangka panjang maupun pendek karena nilai probabilitasnya kurang dari $\alpha 5 \%$.

Christianto (2013), dalam penelitiannya menyimpulkan bahwa konsumsi beras perkapita berpengaruh positif terhadap volume impor beras di Indonesia dan signifikan. Hal ini berarti, ketika konsumsi beras perkapita di Indonesia meningkat, maka volume impor beras di Indonesia akan semakin meningkat. Adanya peningkatan konsumsi dimasyarakat karena persepsi masyarakat Indonesia yang menganggap beras sebagai makananan pokok mereka dan anggapan mengonsumsi beras berarti dapat mendapat suatu kebanggan dan gengsi dari orang lain.

Manurung (2014), dalam penelitiannya menyatakan bahwa dalam jangka pendek produksi beras Indonesia berpengaruh negatif dan signifikan terhadap besarnya impor beras Indonesia dan dalam jangka panjang produksi beras Indonesia berpengaruh negatif dan signifikan terhadap besarnya impor beras Indonesia. Dalam jangka pendek konsumsi beras Indonesia tidak berpengaruh terhadap besarnya impor beras Indonesia dan dalam jangka panjang konsumsi beras Indonesia tidak berpengaruh terhadap impor beras Indonesia. Dalam jangka pendek harga beras lokal berpengaruh postif dan signifikan terhadap besarnya impor beras Indonesia dan dalam jangka panjang harga beras lokal berpengaruh positif dan signifikan terhadap besarnya impor beras Indonesia. Dalam jangka pendek harga beras internasional berpengaruh positif dan signifikan terhadap besarnya impor beras Indonesia dan dalam jangka panjang harga beras internasional berpengaruh positif dan signifikan terhadap besarnya impor beras Indonesia.

\section{Metode Penelitian}

Metode penelitian yang digunakan dalam penelitian ini menggunakan pendekatan Jenis data yang digunakan adalah data sekunder. Data sekunder adalah jenis data yang diperoleh secara tidak langsung atau dengan kata lain, data sekunder adalah data yang diperoleh melalui sumber-sumber yang sudah dikumpulkan oleh pihak-pihak tertentu seperti dokumentasi, publikasi, karya ilmiah, ataupun catatan khusus dari dinas atau lembaga, dan pihak-pihak tertentu yang berhubungan dengan penelitian.

Metode analisis yang digunakan adalah Vector Auto Regressive (VAR)/ Vector Error Correction Model (VECM). Proses analisis VAR dan VECM dilakukan melalui beberapa tahap. Tahap pertama adalah uji unit roots test yang bertujuan untuk mengetahui data stasioner atau tidak. Setelah data dinyatakan stasioner, langkah selanjutnya adalah pengujian kointegrasi. Uji kointegrasi bertujuan untuk menentukan analisis yang digunakan dalam penelitian, jika data terkointegrasi maka analisis yang baik digunakan 
adalah VECM. Dalam penelitian ini, penulis menggunakan perangkat lunak " Eviews 7.2" untuk menganalisis data yang telah dihimpun.

Menurut (Gujarati, 2006) dalam Junarta (2016) menjelaskan bentuk persamaan uji stasioneritas dengan analisis ADF dalam persamaan berikut:

$\Delta F_{t}=\alpha_{0}+\gamma F_{t-1}+6 \Sigma \sum_{i=1}^{p} \Delta F_{t-i+1}+\varepsilon_{t}$

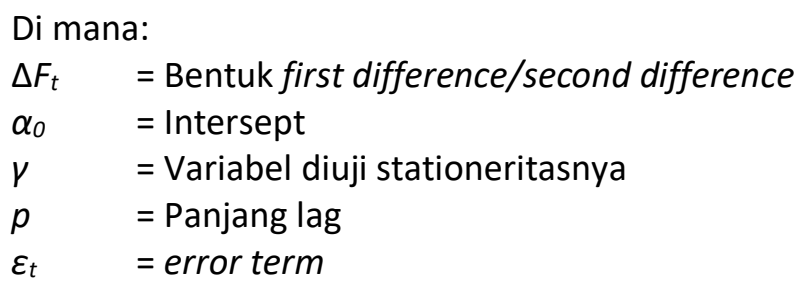

Dalam persamaan tersebut diketahui bahwa hipotesis nol $\left(\mathrm{H}_{0}\right)$ menunjukkan adanya unit root dan hipotesis satu $\left(\mathrm{H}_{1}\right)$ menunjukkan tidak ada unit root. Jika dalam uji stasioneritas ini menunjukkan nilai $\mathrm{ADF}_{\text {statistik }}$ lebih besar dari Mackinnon Critical Value, maka dapat diketahui bahwa data tersebut stasioner karena tidak mengandung unit root. Sebaliknya jika nilai $A \mathrm{DF}_{\text {statistik }}$ lebih kecil dari Mackinnon critical value, maka dapat diketahui data tersebut tidak stasioner pada derajat level. Dengan demikian harus dilakukan uji ADF dalam bentuk first difference. Jika data belum juga stasioner kemudian dilanjutkan pada differensiasi ketiga, yakni pada 2nd difference untuk memperoleh data yang stasioner pada derajat yang sama.

Dari estimasi VECM (Vector Error Correction Model) di atas, akan menghasilkan analisis penting dalam model VAR, yaitu analisis Impuls Response Function (IFR). Analisis IRF adalah metode yang digunakan untuk menentukan respon suatu variabel endogen terhadap guncangan (guncangan) variabel tertentu. IRF juga digunakan untuk melihat guncangan dari satu variabel lain dan berapa lama pengaruh tersebut terjadi. Melalui IRF, respon sebuah perubaha independen sebesar satu standar deviasi dapat ditinjau. IRF menelusuri dampak gangguan sebesar satu standar kesalahan (standard error) sebagai inovasi pada sesuatu variabel endogen terhadap variabel endogen yang lain. Suatu inovasi pada satu variabel, secara langsung akan berdampak pada variabel yang bersangkutan, kemudian dilanjutkan ke semua variabel endogen yang lain melalui struktur dinamik dari VAR (Basuki \& Prawoto, 2016).

Selanjutnya, perlu dilakukan analisis Forecast Error Variance Decomposition (FEVD) atau dekomposisi ragam kesalahan peramalan menguraikan inovasi pada suatu variabel terhadap komponen-komponen variabel yang lain dalam VAR. Informasi yang disampaikan dalam FEVD adalah proporsi pergerakan secara berurutan yang diakibatkan oleh guncangan sendiri dan variabel lain (Basuki \& Prawoto, 2016). 
Analisis Faktor-faktor yang Mempengaruhi Impor Daging Sapi di Indonesia Periode 1988-2017: ...

\section{Hasil dan Pembahasan}

Tahap pertama yang harus dilalui untuk mendapatkan estimasi VECM adalah pengujian stasioneritas data masing-masing variabel, baik variabel dependen, maupun variabel independen. Seperti yang telah dijelaskan di atas, data stasioner dibutuhkan untuk mempengaruhi hasil pengujian estimasi VECM. Persamaan regresi dengan variabelvariabel yang tidak stasioner, akan menghasilkan apa yang disebut regresi lancung atau spurious regression (Winarno, 2015). Adapun uji stasioner ADF masing-masing variabel dapat ditunjukkan oleh tabel 3 berikut ini:

Tabel 3 Hasil Uji ADF Menggunakan Intercept pada Tingkat Level

\begin{tabular}{lcccc}
\hline \multicolumn{1}{c}{ Variabel } & ADF t- Statistik & Mc Kinnon Critical Value 5 Persen & Prob. & Keterangan \\
& & & & \\
\hline Impor Daging Sapi & -1.547 & -2.967 & 0.495 & Tidak Stasioner \\
Produksi Daging Sapi & -1.185 & -2.971 & 0.666 & Tidak Stasioner \\
Penduduk & -5.660 & -2.967 & 0.000 & Stasioner \\
PDB & -0.468 & -2.967 & 0.883 & Tidak Stasioner \\
Inflasi & -5.628 & -2.967 & 0.000 & Stasioner \\
\hline
\end{tabular}

Sumber: Data Diolah (Eviews 7.2)

Dari tabel 3 dapat dijelaskan bahwa ada 2 variabel yang stasioner pada tingkat level yaitu penduduk dan inflasi. Keadaan tersebut dapat diketahui bawha pada probabilitas ADF t- Statistik variabel penduduk dan inflasi daripada nilai Mc Kinnnon Critical Value 5 persen (dalam penelitian ini digunakan a 0,05 ) yaitu dimana penduduk $-5.660<-2.967$ dan inflasi -5.628<-2.967. Artinya, $\mathrm{H}_{0}$ di tolak dan $\mathrm{H}_{1}$ diterima atau dengan kata lain data sudah stasioner.

Tabel 4 Hasil Uji ADF Menggunakan Intercept pada Tingkat 1st Difference

\begin{tabular}{lcccc}
\multicolumn{1}{c}{ Varibale } & ADF t-Statistik & $\begin{array}{c}\text { Mc Kinnon Critical Value } \\
5 \text { persen }\end{array}$ & Prob & Keterangan \\
\hline Impor Daging Sapi & -6.465 & -2.971 & 0.000 & Stasioner \\
Produksi Daging Sapi & -7.146 & -2.971 & 0.000 & Stasioner \\
Penduduk & -4.183 & -3.012 & 0.004 & Stasioner \\
PDB & -4.040 & -2.971 & 0.004 & Stasioner \\
Inflasi & -6.616 & -2.976 & 0.000 & Stasioner \\
\hline
\end{tabular}

Sumber : Data Diolah (Eviews 7.2)

Dari pengujian pada tabel 4, semua variabel telah memenuhi persyaratan stasioneritas data uji ADF dimana, nilai ADF t-Statistik lebih kecil daripada nilai Mc Kinnon Critical Value10 persen pada tingkat 1st difference. Oleh karena itu semua variabel data sudah stasioner pada tingkat 1st difference, maka dapat dilakukan langkah selanjutnya dalam estimasi VECM, yaitu penentuan panjang lag optimal.

Dalam penelitian ini, penentuan panjang lag dilakukan dengan melihat nilai tertinggi dari sequential modified LR test statistic. Panjang lag yang diikutsertkan dalam penelitian ini adalah mulai dari 0 sampai dengan $\operatorname{lag} 1$, karena data yang dipakai adalah tahuanan (annual) dan hanya 30 tahun. Panjang lag tersebut dirasa cukup untuk menggambarkan 
Analisis Faktor-faktor yang Mempengaruhi Impor Daging Sapi di Indonesia Periode 1988-2017: ...

impor daging sapi dalam periode pada tahun 1988 sampai tahun 2017. Panjang lag optimal dapat ditunjukkan dalam tabel 5 sebagai berikut:

Tabel 5 Pengujian Panjang Lag Menggunakan Nilai LR

\begin{tabular}{cc|}
\hline Panjang Lag & \\
& Nilai Sequential Modified LR Test Statistc \\
\hline $\mathbf{0}$ & NA \\
$\mathbf{1}$ & $87.798^{*}$ \\
\hline
\end{tabular}

Sumber : Data Diolah (Eviews 7.2)

Dari tabel 5 di atas, dapat dilihat bahwa panjang lag optimal terletak pada lag 1, yaitu dengan nilai sequential modified LR test statistic tertinggi, yaitu sebesar 87.798. Oleh karena itu, lag optimal yang digunakan dalam penelitian ini adalah lag 1. Panjang lag optimal sudah ditemukan, maka dapat dilakukan pengujian selanjutnya, yaitu uji kointegrasi.

Syarat dalam estimasi VECM, yaitu ada hubungan kointegrasi di dalamnya. Apabila tidak terdapat hubungan kointegrasi, maka estimasi VECM batal digunakan, melainkan harus menggunakan model VAR (Vector Autoregression). Dalam penelitian ini, pengujian kointegrasi digunakan metode Johansen's Cointegration Test yang tersedia dalam software Eviews 7 dengan critical value 0,05. Hasil uji kointegrasi ditunjukkan oleh tabel 6 sebagai berikut:

Tabel 6 Hasil Uji Kointegrasi (Johansen's Cointegration Test)

\begin{tabular}{lllll}
\hline Hypothesized No. Of CE(s) & Eigenvalue & Trace Statistic & 0.05 Critical Value & Prob.** \\
& & & & \\
\hline None ${ }^{*}$ & 0.786 & 91.191 & 69.818 & 0.000 \\
At most 1 & 0.555 & 47.920 & 47.856 & 0.049 \\
At most 2 & 0.398 & 25.222 & 29.797 & 0.153 \\
At most 3 & 0.291 & 10.999 & 15.494 & 0.211 \\
At most 4 & 0.046 & 1.339 & 3.841 & 0.247 \\
\hline
\end{tabular}

Trace test indicates 2 cointegrating eqn(s) at the 0.05 level

* denotes rejection of the hypothesis at the 0.05 level

**MacKinnon-Haug-Michelis (1999) p-values

Sumber : Data Diolah (Eviews 7.2)

Dari tabel 6, dapat dijelaskan bahwa dalam taraf uji 5 persen, terdapat dua rank variabel berhubungan kointegrasi. Hal tersebut terbukti dari nilai Trace Statistic 91.191 dan 47.920 lebih besar dari Critical Value 0,05 yaitu 69.818 dan 47.856 yang artinya, $\mathrm{H}_{0}$ ditolak atau dengan kata lain, variabel-variabel yang digunakan memiliki hubungan dalam jangka panjang (kointegrasi) satu dengan lainnya. Oleh karena itu, estimasi VECM dalam penelitian ini dapat digunakan dan selanjutnya dapat dilakukan uji stabilitas VECM.

Pengujian stabilitas model merupakan langkah selanjutnya sebelum kita menggunakan estimasi VECM. Pengujian stabilitas model, dimaksud untuk menguji validitas IRF dan 
Analisis Faktor-faktor yang Mempengaruhi Impor Daging Sapi di Indonesia Periode 1988-2017: ...

VDC. Pengujian stabilitas estimasi VECM dapat ditunjukkan dalam tabel 7 sebagai berikut:

Tabel 7 Hasil Uji Stabilitas Estimasi VECM

\begin{tabular}{|c|c|}
\hline+2 & Modulus \\
\hline 0.657 & 0.657 \\
\hline$-0.314-0.184 i$ & 0.363 \\
\hline$-0.314+0.184 i$ & 0.363 \\
\hline-0.279 & 0.279 \\
\hline 0.179 & 0.179 \\
\hline
\end{tabular}

Sumber : Data Diolah (Eviews 7.2)

Dari tabel 7 dapat dijelaskan bahwa model yang digunakan sudah stabil. Hal tersebut dapat diketahui dari kisaran modulus dengan nilai rata-rata kurang dari satu. Dengan demikian hasil analisis IRF (Impulse Response Function) dan VDC (Variance Decomposition) adalah valid dan dapat dilakukan pengujian selanjutnya, yaitu uji kausalitas granger.

Dalam penelitian ini, uji kausalitas lebih ditujukan pada faktor-faktor penyebab terjadinya impor daging sapi di Indonesia, yaitu, produksi daging sapi, Produk Domestik Bruto (PDB), jumlah penduduk, dan inflasi yang mempengaruhi impor daging sapi. Taraf uji yang digunakan dalam uji kausalitas granger ini, yaitu pada tingkat kepercayaan 5 persen dan panjang lag sampai pada lag 1 sesuai pengujian panjang lag optimum yang telah dilakukan. Hasil uji kausalitas granger ditunjukkan dalam tabel 1.8 sebagai berikut:

Tabel 8 Uji Kausalitas Granger

\begin{tabular}{lccc}
\multicolumn{1}{c}{ Null Hypothesis: } & Obs & \multicolumn{2}{c}{ Lag1 } \\
\hline LOG_PRODUKSI doesn't Granger Cause LOG_IMPOR & 29 & 5.362 & 0.028 \\
\hline LOG_IMPOR doesn't Granger Cause LOG_PRODUKSI & & 747.816 & 0.011 \\
\hline LOG_PENDUDUK doesn't Granger Cause LOG_IMPOR & 29 & 9.626 & 0.004 \\
\hline LOG_IMPOR doesn't Granger Cause LOG_PENDUDUK & & 0.032 & 0.857 \\
\hline LOG_PDB doesn't Granger Cause LOG_IMPOR & 29 & 12.682 & 0.001 \\
\hline LOG_IMPOR doesn't Granger Cause LOG_PDB & & 0.841 & 0.367 \\
\hline INFLASI doesn't Granger Cause LOG_IMPOR & 29 & 0.026 & 0.872 \\
\hline LOG_IMPOR doesn't Granger Cause INFLASI & & 0.218 & 0.643 \\
\hline
\end{tabular}

Sumber : Data Diolah (Eviews 7.2)

Dari tabel 8 dapat dilihat bahwa variabel produksi daging sapi secara statistik mempengaruhi impor daging sapi yaitu dengan nilai prob (0.028) sehingga menolak hipotesis nol. Sebaliknya variabel impor daging sapi secara statistik juga mempengaruhi produksi daging sapi yaitu dengan nilai prob (0.011) sehingga menolak hipotesis nol. Dengan demikian, disimpulkan bahwa terjadi kausalitas antara kedua variabel yaitu produksi daging sapi dan impor daging sapi yang secara statistik signifikan mempengaruhi.

Penggunaan estimasi VECM sesuai dengan rumusan masalah dalam penelitian ini, yaitu untuk mengidentifikasi hubungan jangka pendek dan jangka panjang pengaruh variabel 
independen terhadap variabel dependen. Adapun hasil estimasi VECM dapat ditunjukkan dalam tabel 9 sebagai berikut:

Tabel 9 Hasil Estimasi VECM (Vector Error Correction Model) Jangka Pendek

\begin{tabular}{lcc}
\hline \multicolumn{1}{c}{ Variabel } & Koefisien & t-Statistik Parsial \\
\hline D(LOG_PDB(-1)) & 38.452 & {$[2.893]$} \\
D(INFLASI(-1)) & -0.026 & {$[-3.280]$} \\
\hline
\end{tabular}

Sumber : Data Diolah (Eviews 7.2)

Dari tabel 9 dilihat bahwa hasil estimasi VECM dapat dijelaskan dalam jangka pendek (satu tahun sesuai jenis data yang digunakan, yaitu data edisi tahunan dalam periode 1988-2017). Hanya terdapat dua variabel independen pada lag 1 yang berpengaruh signifikan terhadap impor daging sapi, yaitu PDB (lag 1) dan inflasi (lag 1). Dalam estimasi VECM dalam jangka pendek di atas, dapat dijelaskan bahwa PDB pada lag 1 berpengaruh positif dan signifikan terhadap impor daging sapi, yaitu sebesar 38.452 . Artinya, apabila terjadi kenaikan Produk Domestik Bruto (PDB) sebesar satu miliyar pada satu tahun sebelumnya, maka akan menaikkan impor daging sapi pada tahun sekarang sebesar 38.452 poin.

Hasil analisis tersebut telah sesuai dengan hipotesis dimana, nilai t-statistik parsial variabel Produk Domestik Bruto (PDB) pada lag 1 sebesar 2.893 atau lebih besar dari 2,021 yang artinya $\mathrm{H}_{0}$ ditolak atau dengan kata lain, variabel Produk Domestik Bruto (PDB) berpengaruh positif dan signifikan terhadap impor daging sapi dalam jangka pendek. Hasil penelitian ini yang menunjukkan pengaruh positif antara Produk Domestik Bruto (PDB) dengan impor daging sapi sesuai dengan penelitian yang dilakukan oleh Hengki Kurniyawan (2013) yang menyatakan bahwa Produk Domestik Bruto (PDB) secara parsial berpengaruh signifikan terhadap impor daging sapi di Indonesia dengan arah koefesien positif. Selain itu, hasil estimasi ini telah sesuai dengan teori permintaan impor dimana, Produk Domestik Bruto (PDB) negara pengimpor, dalam teori dasar perdagangan internasional dinyatakan bahwa impor merupakan fungsi dari pendapatan. Pendapatan disini bisa juga PDB, semakin besar pendapatan menyebabkan impor semakin meningkat.

Dalam estimasi VECM dalam jangka pendek dijelaskan bahwa variabel inflasi pada lag 1 berpengaruh negatif dan signifikan terhadap impor daging sapi yaitu sebesar -0.026 . Hasil analisis tersebut telah sesuai dengan hipotesis dimana, nilai t-statistik parsial variabel inflasi pada lag 1 sebesar - 3.280 atau lebih besar dari -2,021 yang artinya $\mathrm{H}_{0}$ ditolak atau dengan kata lain, variabel inflasi berpengaruh negatif dan signifikan terhadap impor daging sapi dalam jangka pendek. Begitu juga dengan variabel inflasi dalam jangka panjang pada lag 1 berpengaruh negatif dan signifikan yaitu sebesar 0.249 . Hasil analisis tersebut sesuai dengan hipotesis dimana, nilai t-statistik parsial variabel inflasi pada lag 1 sebesar -8.657 atau lebih besar dari -2.021 yang artinya $\mathrm{H}_{0}$ ditolak atau dengan kata lain variabel inflasi dalam jangka panjang berpengaruh negatif dan signifikan terhadap impor daging sapi. 
Kedua hal ini bisa terjadi dikarenakan harga dari daging sapi itu sendiri tergolong tinggi. Sehingga ketika harga daging sapi tinggi maka akan menyumbang pengaruh yang besar terhadap inflasi. Hasil penelitian ini juga sesuai dengan hasil penelitian Pakpahan (2012) yang menyatakan bahwa inflasi memiliki pengaruh negatif dan signifikan terhadap impor daging sapi.

Perbedaan hasil penelitian ini dengan hipotesis dan penelitian-penelitian sebelumnya juga dikarenakan inflasi yang meningkat di dalam negeri akan membuat pemerintah mengambil langkah-langkah dalam memperbaiki perekonomian di dalam negerinya. Pemerintah akan mengambil kebijakan-kebijakan yang akan mengurangi inflasi dalam negeri seperti kebijakan mengurangi impor dan meningkatkan produksi dalam negeri. Ini akan menyebabkan impor menurun seiring terjadinya peningkatan inflasi dalam negeri.

Selanjutnya dalam jangka panjang (tiga puluh tujuh tahun sesuai periode penelitian, yaitu 1988-2017) diketahui variabel produksi daging sapi,variabel PDB dan inflasi berpengaruh terhadap impor daging sapi, sedangkan variabel jumlah penduduk tidak mempengaruhi impor. Hasil estimasi VECM dalam jangka panjang di tunjukkan pada tabel 1.10 sebagai berikut :

Tabel 10 Hasil Estimasi VECM (Vector Error Correction Model) Jangka Panjang

\begin{tabular}{lll}
\hline Variabel & Koefisien & t-Statistik Parsial \\
\hline LOG_PRODUKSI(-1) & 9.790 & {$[2.851]$} \\
LOG_PDB(-1) & $-11,969$ & {$[-3.451]$} \\
INFLASI(-1) & -0.249 & {$[-8.657]$} \\
\hline
\end{tabular}

Sumber : Data Diolah (Eviews 7.2)

Dari Tabel 10 Estimasi VECM dalam jangka panjang di atas, menunjukkan bahwa variabel produksi daging sapi pada lag 1 berpengaruh positif dan signifikan terhadap impor daging sapi, yaitu sebesar 9.790. Hasil analisis tersebut telah sesuai dengan hipotesis dimana, nilai t-statistik parsial variabel produksi daging sapi pada lag 1 sebesar 2.851 atau lebih besar dari +2.021 yang artinya $\mathrm{H}_{0}$ ditolak, dengan kata lain, variabel produksi berpengaruh positif dan signifikan terhdap impor daging sapi dalam jangka panjang.

Hal ini dikarenakan produksi daging sapi memiliki kaitan yang erat dengan permintaan pasar pada negara tersebut. Di mana permintaan pasar yang banyak akan sangat mempengaruhi kebijakan yang akan di ambil oleh pemerintah. Karena pemerintah dituntut untuk mampu memenuhi stock permintaan dari pasar.

Hasil estimasi VECM dalam jangka panjang, dapat dijelaskan bahwa PDB pada lag 1 berpengaruh negatif dan signifikan terhadap impor daging sapi, yaitu sebesar -11,969. Artinya, apabila terjadi kenaikan PDB sebesar 1 milyar pada satu tahun sebelumnya, maka akan menurunkan impor daging sapi pada tahun sekarang sebesar $-11,969$. Nilai tstatistik parsial variabel PDB sebesar -3.451 atau lebih besar dari -2.021 yang artinya $\mathrm{H}_{0}$ di tolak atau dapat dikatakan variabel PDB berpengaruh negatif signifikan terhadap impor daging sapi. 
Hasil penelitian ini sesuai dengan penelitian yang dilakukan oleh Wijaya (2017) bahwa PDB berpengaruh negatif dan signifikan terhadap impor daging sapi. Hal ini dikarenakan pemerintah mempunyai sebuah program yang dapat memperbaiki jumlah populasi sapi Indonesia yaitu dengan program SIWAB (Sapi Induk Wajib Bunting) untuk jangka panjang. Program SIWAB ini dilakukan agar Indonesia mampu swasembada daging sapi.

Estimasi VECM jangka panjang menunjukkan bahwa variabel inflasi pada lag 1 berpengaruh negatif dan signifikan terhadap impor daging sapi yaitu sebesar -0.249. Hasil analisis tersebut telah sesuai dengan hipotesis dimana, nilai t-statistik parsial variabel inflasi pada lag 1 sebesar -8.657 atau lebih besar dari -2.021 yang artinya, $\mathrm{H}_{0}$ di tolak atau dengan kata lain, variabel inflasi berpengaruh negatif dan signifikan terhadap impor daging sapi dalam jangka panjang. Hasil estimasi VECM dalam jangka panjang dan jangka pendek di atas merupakan hasil yang valid dimana, diketahui dari nilai koefisien determinan R-Square sebesar 0.446 atau 44.6 persen dari 1.00 persen atau 100 persen dimana, perubahan variabel dependen (impor daging sapi) mampu dijelaskan oleh variabel independennya (produksi daging sapi,jumlah penduduk,PDB, inflasi) sebesar 44.6 persen dari maksimal 100 persen.

Hasil estimasi VECM tidak hanya mampu melihat pengaruh variabel independen terhadap variabel dependen namun dalam estimasi VECM juga dilengkapi dengan fitur IRF (Impulse Response Function) dan VDC (Variance Decomposition) untuk melihat respon dan waktu yang dibutuhkan variabel kembali ke titik keseimbangannya serta melihat seberapa besar komposisi pengaruh masing-masing variabel independen terhadap pembentukan variabel dependennya.

IRF digunakan untuk menjelaskan dampak dari guncangan (guncangan) pada satu variabel terhadap variabel lain, dimana dalam analisis ini tidak hanya dalam jangka pendek tetapi dapat menganalisis untuk beberapa horizon kedepan sebagai informasi jangka panjang. Pada analisis ini dapat melihat respon dinamika jangka panjang setiap variabel apabila ada guncangan tertentu sebesar satu standar error pada setiap persamaan. Analisis IRF (Impulse Response function) juga berfungsi untuk melihat berapa lama pengaruh tersebut terjadi. Sumbu horizontal merupakan periode dalam tahun, sedangkan sumbu vertikal menunjukkan nilai respon dalam persentase. Hasil dari analisis IRF (Impulse Response Function) dapat dilihat dari pada berikut ini :

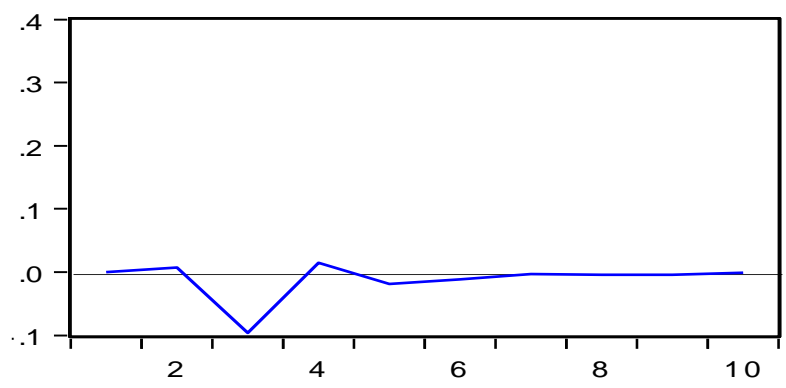

Response of LOG_IMPOR to LOG_PRODUKSI

Gambar 1 Hasil Analisis IRF Impor Daging Sapi terhadap guncangan Produksi Daging Sapi 
Dari Gambar 1 dijelaskan bahwa respon impor daging sapi terhadap guncangan variabel produksi daging sapi adalah dari perode pertama sampai periode ketiga mengalami penurunan dan menunjukkan tren negatif. Akan tetapi respon impor daging sapi terhadap guncangan produksi daging sapi mulai meningkat pada periode keempat dengan menunjukkan trend positif. Pada periode kelima respon impor daging sapi terhadap guncangan produksi daging sapi mengalami penurunan dengan menunjukkan trend negatif. Kemudian pada periode keenam sampai periode kesepuluh respon impor daging sapi terhadap guncangan produksi daging sapi terus meningkat dan menunjukkan trend positif.

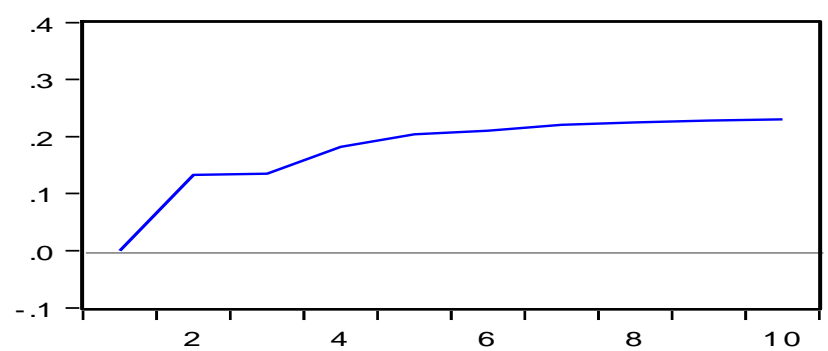

Respone of LOG_IMPOR to LOG_PENDUDUK

Gambar 2 Hasil Analisis IRF Impor Daging Sapi terhadap Guncangan Penduduk

Dari Gambar 2 dapat dijelaskan bahwa respon impor daging sapi terhadap guncangan variabel penduduk mengalami trend positif pada periode pertama hingga periode kesepuluh. Hal ini ditunjukkan dari garis IRF yang cenderung meningkat keatas sampai periode kesepuluh. Hal ini dikarenakan produksi daging sapi tidak mencukupi kebutuhan konsumsi yang semakin meningkat, maka negara tersebut akan melakukan impor yang dimana impor akan menjadi meningkat positif.

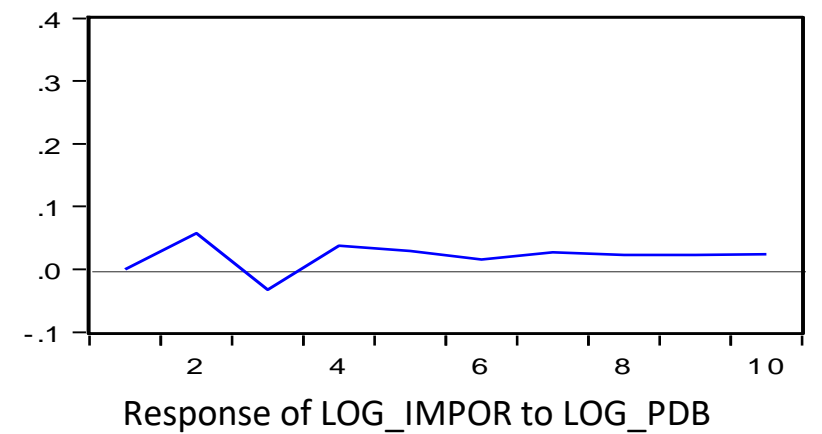

Gambar 3 Hasil Analisis IRF Impor Daging Sapi terhadap Guncangan PDB

Dari Gambar 3 dapat dijelaskan bahwa respon impor daging sapi terhadap guncangan variabel PDB dari periode pertama sampai periode kedua mengalami kenaikan dan menunjukkan trend postif. Akan tetapi respon impor daging sapi terhadap guncangan PDB mulai menurun pada periode ketiga dan menunjukkan trend negatif. Kemudian pada periode keempat sampai periode sepuluh mengalami trend positif. Walaupun pada periode keempat sampai periode keenam mengalami sedikit penurunan, setelah itu pada periode ketujuh cukup meningkat dan periode kedelapan sampai sepuluh 
mengalami sedikit penurunan tetapi tetap menunjukkan trend positif terhadap respon impor daging sapi terhadap guncangan PDB.

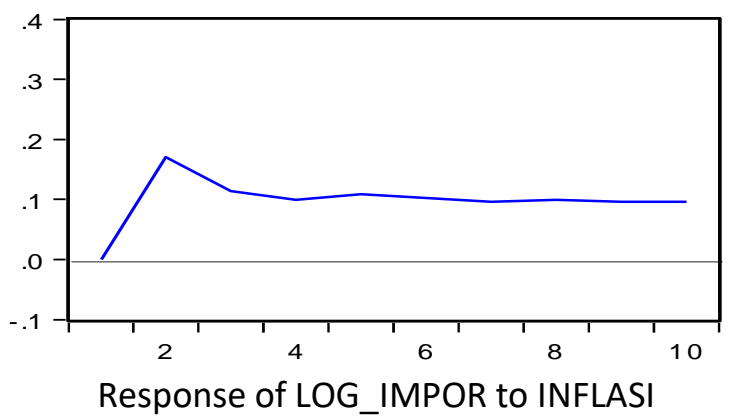

Gambar 4 Hasil Analisis IRF Impor Daging Sapi terhadap guncangan Inflasi

Dari Gambar 4 dapat dijelaskan bahwa respon impor daging sapi terhadap guncangan variabel inflasi dari periode pertama sampai periode kesepuluh mengalami trend positif. Hal tersebut ditunjukkan dari garis IRF yang cenderung di atas garis horizontal sampai periode kesepuluh. Pada periode kedua respon impor daging sapi terhadap guncangan inflasi mengalami peningkatan dengan menunjukkan trend positif. Kemudian pada periode keempat mengalami penurunan, setelah itu pada periode kelima sampai periode kesepuluh mengalami sedikit peningkatan dan penurunan yang tetap menunjukkan trend positif. Respon impor daging sapi terhadap guncangan variabel inflasi yang berada di trend positif.

Selain IRF, Variance Decomposition juga digunakan untuk menyusun forecast error variance suatu variabel, yaitu seberapa besar perbedaan antara variance sebelum dan sesudah guncangan, baik guncangan yang berasal dari diri sendiri maupun guncangan dari variabel lain untuk melihat pengaruh relatif variablevariabel penelitian terhadap variabel lainnya. Prosedur Variance Decomposition yaitu dengan mengukur persentase kejutan-kejutan atas masing-masing variabel. Dimana digunakan untuk memberikan penjelasan secara rinci mengenai bagaimana perubahan satu variabel yang dipengaruhi oleh perubahan variabel lainnya. Perubahan yang terjadi dalam variabel ditunjukkan dengan adanya perubahan error variance. Hasil uji VDC dapat dilihat pada Tabel 11 berikut ini:

Tabel 11 Hasil Analisis VDC Impor Daging Sapi

\begin{tabular}{|c|c|c|c|c|c|c|}
\hline \multicolumn{7}{|c|}{ Variance Decomposition of LOG_IMPOR } \\
\hline Periode & S.E. & LOG_IMPOR & LOG_PRODUKSI & LOG_PENDUDUK & LOG_PDB & INFLASI \\
\hline 1 & 0.351 & 100.00 & 0.000 & 0.000 & 0.000 & 0.000 \\
\hline 2 & 0.509 & 80.79 & 0.018 & 6.755 & 1.289 & 11.141 \\
\hline 3 & 0.619 & 76.20 & 2.434 & 9.327 & 1.137 & 10.891 \\
\hline 4 & 0.712 & 73.19 & 1.885 & 13.608 & 1.132 & 10.177 \\
\hline 5 & 0.796 & 69.95 & 1.566 & 17.423 & 1.042 & 10.017 \\
\hline 6 & 0.871 & 67.65 & 1.327 & 20.361 & 0.903 & 9.753 \\
\hline 7 & 0.940 & 65.64 & 1.139 & 22.943 & 0.859 & 9.410 \\
\hline 8 & 1.006 & 63.94 & 0.998 & 25.059 & 0.802 & 9.198 \\
\hline 9 & 1.067 & 62.56 & 0.888 & 26.806 & 0.757 & 8.981 \\
\hline 10 & 1.125 & 61.39 & 0.799 & 28.276 & 0.725 & 8.803 \\
\hline
\end{tabular}

Sumber : Data Diolah (Eviews 7.2) 
Dari Tabel 11, dapat dijelaskan bahwa pada periode pertama impor daging sapi sangat dipengaruhi oleh guncangan impor daging sapi itu sendiri sebesar 100 persen. Sementara itu pada periode pertama variabel produksi, jumlah penduduk, PDB dan inflasi belum memberikan pengaruh terhadap impor daging sapi. Akan tetapi guncangan impor daging sapi dari periode 1 sampai periode ke 10 mengalami penurunan yang cukup besar. Pada periode ke-2 sampai periode ke-10 guncangan impor daging sapi terhadap impor daging sapi itu sendiri mengalami penurunan dengan memberikan pengaruh sebesar 80.79 persen dan 61.395 persen pada periode ke-10.

Selanjutnya variabel produksi daging sapi pada periode ke-2 memberikan kontribusi pada impor daging sapi sebesar 0.018 persen. Pada periode ke-3 besar guncangan produksi daging sapi terhadap impor daging sapi meningkat sebesar 2.43 persen. Setelah iu pada periode ke-4 sampai periode ke-10 guncangan produksi daging sapi menurun sebesar 0.79 perssen.

Pada variabel jumlah penduduk pada periode ke-2 memberikan kontribusi pada impor daging sapi sebesar 6.75 persen dan seterusnya menunjukkan peningkatan sampai periode ke10. Pada setiap periode diketahui bahwa jumlah penduduk memberikan tambahan kontribusi, sehingga setiap periode selalu mengalami peningkatan. Peningkatan sedikit demi sedikit dari periode ke-2 sampai periode ke-10, dengan besar guncangan 6.75 persen pada periode ke-2 dan terus meningkat sampai besar guncangan 28.27 persen pada periode ke-10.

Selanjutnya variabel PDB pada periode ke-2 memberikan kontribusi pada impor daging sapi sebesar 1.28 persen. Kontribusi PDB terhadap impor daging sapi dari periode ke-2 sampai periode ke-10 dapat dikatakan menurun, karena dengan besar guncangan yang selalu berkurang dari setiap periode. Kontribusi guncangan PDB terhadap impor daging sapi selalu mengalami penurunan yang dittunjukkan dari besar guncangan 1.28 persen pada periode ke- 2 dan terus menurun sampai besar guncangan 0.72 persen pada periode ke-10.

Kemudian variabel inflasi pada periode ke-2 memberikan kontribusi pada impor daging sapi sebesar 11.14 persen. Kontribusi inflasi terhadap impor daging sapi dari priode ke-2 sampai periode ke-10 dapat dikatakan menurun, karena dengan besar guncangan yang selalu berkurang dari setiap periode. Kontribusi guncangan inflasi terhadap impor daging sapii selalu mengalami penurunan yang ditunjukkan dari besar guncangan 11.14 persen pada periode ke- 2 dan terus menurun sampai besar guncangan 8.80 persen pada periode ke-10.

\section{Kesimpulan}

Berdasarkan hasil yang didapatkan dari penelitian yang dilakukan terhadap faktor-faktor yang mempengaruhi impor daging sapi di Indonesia periode 1988-2017 dengan pendekatan Vector Error Correction Model (VECM) didapatkan kesimpulan sebagai berikut, pertama, dalam jangka pendek, PDB pada lag 1 (+) berpengaruh signifikan dan 
inflasi pada lag 1 (-) serta berpengaruh signifikan terhadap impor daging sapi di Indonesia. Sedangkan, produksi daging sapi, jumlah penduduk dalam jangka pendek tidak menunjukkan pengaruh yang signifikan terhadap impor daging sapi di Indonesia. Kedua, dalam jangka panjang, produksi daging sapi pada lag 1(+) berpengaruh signifikan, PDB pada lag 1 (-) berpengaruh signifikan dan inflasi pada lag 1 (-) berpengaruh signifikan terhadap impor daging sapi di Indonesia. Sedangkan, jumlah penduduk dalam jangka panjang tidak menunjukkan pengaruh yang signifikan terhadap impor daging sapi.

Berdasarkan hasil analisis IRF, dapat disimpulkan bahwa respon impor daging sapi terhadap guncangan produksi (-), kemudian mengalami perubahan pada periode ke-2 $(+)$ dan mengalami penurunan pada periode ke-3 (-) setelah itu mengalami kenaikan pada periode ke-4 (+) dan mengalami penurunan pada periode ke-4 sampai periode ke10 (-). Hasil analisis IRF menunjukkan respon impor daging sapi terhadap guncangan jumlah penduduk. Adalah (+) mulai dari periode ke-1 sampai periode ke-10. Hasil analisis IRF menunjukkan respon impor daging sapi terhadap guncangan PDB adalah (+) tetapi pada periode ke-3 mengalami penurunan (-) dan meningkat dari periode 4 sampai dengan periode ke-10 (+). Hasil analisis IRF menunjukkan respon impor daging sapi terhadap guncangan inflasi adalah (+) pada periode ke-1 sampai dengan periode ke-10. Berdasarkan hasil analisis VDC (Variance Decomposition), variabel impor daging sapi, produksi daging sapi, jumlah penduduk, PDB dan inflasi masing-masing memberikan kontribusi yang bervariasi terhadap impor daging sapi di Indonesia. Kontribusi tertinggi terhadap impor daging sapi di Indonesia yaitu impor daging sapi itu sendiri yang memberikan kontribusi hingga di akhir periode sebesar 61 persen.

Bedasarkan hasil penelitian yang telah dilakukan, pemerintah disarankan agar lebih mengutamakan kualitas maupun kuantitas produksi daging sapi di Indonesia sendiri seperti menciptakan peternak-peternak yang modern, sehingga Indonesia tidak selalu mengandalkan impor daging sapi dari luar, bisa memenuhi kebutuhan sapi nasional dan dapat mengurangi impor daging sapi di Indonesia. Selain itu, pemerintah perlu menekan angka inflasi dengan berbagai kebijakan yang diharapkan dapat menaikkan pendapatan Produk Domestik Bruto (PDB).

\section{Daftar Pustaka}

Basuki, A. T., \& Prawoto, N. (2014). Pegantar Teori Ekonomi. Yogyakarta: Mitra Aksara Mulia. Basuki, A. T., \& Prawoto, N. (2016). Analisis Regresi dalam Penelitian Ekonomi dan Bisnis. Yogyakarta: PT Raja Grafindo Persada.

Christianto, E. (2013). Faktor-faktor yang Memengaruhi Volume Impor Beras di Indonesia. Jurnal Jibeka. 7(2), 38-43.

Gujarati, D. N. (2006). Dasar-dasar ekonometrika. Jakarta: Erlangga.

Junarta, O. (2016). Analisis Faktor-faktor yang Mempengaruhi Impor Beras. Skripsi. Universitas Muhammadiyah Yogyakarta.

Kurniyawan, H. (2013). Faktor-Faktor Yang Mempengaruhi Impor Beras di Indonesia Tahun 1980-2009. Skripsi. Universitas Negeri Semarang. 
Manurung, E. (2014). Faktor-Faktor yang Mempengaruhi Impor Beras Indonesia Tahun 1991-2011: Pendekatan Error Correction Model. Jurnal Ilmu Ekonomi. 1-7..

Pakpahan, A. R. S. (2012). Analisis Faktor-Faktor yang Mempengaruhi Impor Daging Sapi di Indonesia. Economics Development Analysis Journal, 1(2). https://doi.org/10.15294/edaj.v1i2.471

Putra, A. A. B. S. O. P., \& Rustariyuni, S. D. (2015). Pengaruh Kurs Dollar Amerika Serikat, Harga Impor, Harga Domestik, Jumlah Produksi Terhadap Volume Impor Daging Sapi di Indonesia Tahun 1998- 2013. E-Journal Ekonomi Pembangunan. 4(9), 1048-1194. Diakses dari https://ojs.unud.ac.id/index.php/eep/article/view/14927

Sari, R. K. (2014). Analisis impor beras di Indonesia. Economics Development Analysis Journal, 3(2). https://doi.org/10.15294/edaj.v3i2.3838

Sudarmono, A. S., \& Sugeng, Y. B. (2018). Panduan Berternak Sapi Potong. Jakarta: Penebar Swadya.

Syamsuddin, N., Hamzah, A., \& Nasir, M. (2013). Analisis Faktor-faktor yang Mempengaruhi Impor Beras di Indonesia. Jurnal Magister Imu Ekonomi, 1(3). Diakses dari http://jurnal.unsyiah.ac.id/MIE/article/view/4534

Wijaya. D. M. (2017). Analisis Faktor-Faktor yang Mempengaruhi Impor Daging Sapi di Indonesia Periode 1980-2016. Skripsi. Universitas Muhammadiyah Yogyakarta.

Winarno, W. W. (2015). Analisis Ekonometrika dan Statistik dengan Ewiews. Yogyakarta: UPP STIM YKPN. 